\title{
Peran dan Tantangan Aktivis Yayasan Gaya Dewata dalam Kegiatan Pencegahan dan Penanggulangan HIV dan AIDS di Provinsi Bali
}

\author{
Ni Made Anggita Sastri Mahadewi \\ Pascasarjana Univeritas Padjadjaran \\ snimadeanggita@yahoo.com
}

\begin{abstract}
This research discusses roles and challenges encountered by the activists of Yayasan Gaya Dewata (Gaya Dewata Foundation) in their efforts to prevent HIV infection and AIDS among gays and transgenders in Bali. This research applies qualitative approach to examine the actions conducted by the activists in three regions of Bali Province: Denpasar City, Badung Regency, and Gianyar Regency. The actions include field and cyber outreach, interactive group discussion, HIV counseling and testing, condom and lubricant distribution to gays and transgenders; and social support for people living with HIV and AIDS (PLHA). This research applies social action and simbolic interactionism theory to analyse several actions by the activists. This research finds that the actions by the activists of demonstrate a rational-instrumental and affective action as well as a symbolic interactionism action in the context of HIV and AIDS prevention.
\end{abstract}

Keywords: Yayasan Gaya Dewata, gays and transgender, HIV, AIDS, Bali

\begin{abstract}
Abstrak
Penelitian ini membahas peran dan tantangan yang dihadapi oleh para aktivis di Yayasan Gaya Dewata dalam upaya mereka mencegah infeksi HIV dan AIDS di kalangan gay dan waria di Bali. Penelitian ini menerapkan pendekatan kualitatif untuk mengamati kegiatan yang dilakukan para aktivis di tiga wilayah di Provinsi Bali: Kota Denpasar, Kabupaten Badung, dan Kabupaten Gianyar. Kegiatan para aktivis meliputi; penjangkauan lapangan dan online, diskusi kelompok interaktif, konseling dan tes HIV, pembagian kondom dan pelican bagi para gay dan waria, dan dukungan sosial bagi orang dengan HIV dan AIDS (ODHA). Penelitian ini menggunakan teori tindakan sosial dan interaksionisme simbolik untuk menganalisis kegiatan yang dilakukan para aktivis. Penelitian ini menemukan bahwa kegiatan yang dilakukan para aktivis menunjukkan sebuah bentuk tindakan sosial rasionalinstrumental dan sebuah interaksi simbolik dalam konteks pencegahan HIV dan AIDS.
\end{abstract}

Kata kunci: Yayasan Gaya Dewata, gay, waria, HIV, AIDS, Bali.

\section{Pendahuluan}

Data Kementerian Kesehatan Repubik Indonesia tahun 2014 menyebutkan bahwa Provinsi Bali menempati peringkat ketiga di Indonesia sebagai provinsi dengan kasus HIVAIDS terbanyak (Kemenkes RI, 2014). Diantara para pengidap HIV dan AIDS di Indonesia, sebagian dari mereka adalah para gay dan waria. Orientasi seksual kedua kelompok ini membuat mereka rentan terinfeksi dan menularkan virus HIV.

Yayasan Gaya Dewata atau dikenal dengan sebutan YGD di Bali adalah sebuah lembaga Swadaya masyarakat (LSM) yang menaungi komunitas gay dan waria di Bali. Yayasan ini berperan aktif dalam menyebarkan informasi tentang pencegahan penularan IMS, HIV-AIDS dengan cara melakukan pendekatan pada para gay, waria dan 
masyarakat umum. Selain menyebarluaskan informasi mengenai HIV dan AIDS, YGD juga melakukan kegiatan pemberdayaan serta pengembangan pendidikan, kesehatan (khususnya kesehatan seksual) dan Hak Asasi Manusia (HAM) melalui pendekatanpendekatan multisektoral.

Penelitian ini membahas peran dan tantangan yang dihadapi oleh para aktivis (yang semuanya juga gay dan waria) di Yayasan Gaya Dewata dalam melaksanakan kegiatan pencegahan dan penanggulangan HIV dan AIDS di tiga Kabupaten/Kota di Provinsi Bali. Penelitian ini menggunakan teori tindakan sosial dan interaksionisme simbolik untuk menganalisis kegiatan para aktivis.

\section{Kajian Pustaka}

\section{Masalah sosial}

Sosiolog mendefinisikan masalah sosial sebagai bentuk pelanggaran adat istiadat yang telah ditetapkan di masyarakat untuk menjamin kesejahteraan hidup bersama. Definisi lain dari masalah sosial merujuk pada situasi sosial yang dianggap mengganggu, tidak dikehendaki, berbahaya, dan merugikan banyak orang. Masalah sosial tidak dapat dihindari dalam kehidupan masyarakat majemuk. Aneka bentuk masalah sosial diantaranya adalah kriminalitas, pelacuran, alkoholisme, termasuk homo-seksualitas (Kartono, 1981: 1-8). Masalah sosial yang menjadi pokok perhatian dalam penelitian ini berkaitan dengan orientasi seksual non-hetero yaitu homoseksualitas, biseksualitas, dan transgenderisme. Orientasi seksual ini muncul akibat faktor biologis individu dan faktor lingkungan keluarga dan faktor pergaulan.

\section{Orientasi seksual}

Masyarakat hanya mengakui dua jenis kelamin, laki-laki dan perempuan, dan juga orientasi seksual hetero. Akibatnya, orangorang dengan jenis kelamin selain laki-laki dan perempuan dan berorientasi seks non hetero kerap dikucilkan dan tidak mendapat mengalami tempat di masyarakat (Kirven, et al., 2010 : 12). Orang-orang dengan orientasi seksual lain yaitu Lesbian, Gay, Biseksual, dan Transgender atau dikenal dengan 'LGBT' dikucilkan dan sering menerima kekerasan dan diskriminasi di masyarakat. Kekerasan dan diskrimasi pada kelompok ini terjadi antara lain di Aceh, Jakarta, Sukabumi, Yogyakarta, Banyumas, Purwokerto, dan Makasar. Wujud kekerasan dan diskriminasi pada kelompok ini terwujud dalam berbagai jenis kasus; teror terhadap organisasi yang menaungi kaum LGBT hingga penganiayaan bahkan pembunuhan orang yang diketahui sebagai LGBT (Arianto dan Triawan, 2008).

Kemunculan kelompok lesbian, gay, biseksual, dan transgender (LGBT) di Indonesia dianggap sebagai masalah sosial karena masyarakat menganggap orientasi seksual mereka bertentangan dengan adat istiadat, agama, dan juga nilai-nilai kemasyarakatan. Namun, menurut para aktivis LGBT, kemunculan kaum LGBT bukanlah masalah sosial, melainkan sebuah perbedaan status sosial yang hendaknya dapat diterima dan tidak menjadi konflik berkepanjangan di masyarakat. Dengan demikian, mereka menyanyangkan berbagai bentuk penolakan masyarakat terhadap kaum LGBT (Kirven et al., 2010).

Berbagai kajian tentang kelompok gay dan waria telah dilakukan. Ratu (2012) melakukan penelitian terhadap wacana homo seksualitas di dalam film All You Need Is Love - Maine Schwiegretochter ist Eein Mann dalam kaitannya dengan konsep heteroseksualitas. Penelitian itu menyoroti fenomena homoseksualitas laki-laki yang telah dilegalkan oleh pemerintah Jerman, namun tidak mendapat dukungan sepenuhnya oleh beberapa bagian masyarakat. Ratu menyimpulkan bahwa film ini mengkritik masyarakat yang intoleran dan menawarkan perspektif humanis dalam menyikapi isu homoseksual. Arianto dan Triawan (2008), melakukan penelitian kasus diskriminasi dan kekerasan terhadap kelompok LBGT di di Indonesia. Penelitian dilakukan di delapan daerah, yaitu Sulawesi Selatan, Yogyakarta, Jakarta, Sukabumi, Purwokerto, Banyumas, 
Aceh, dan Makassar. Hasil penelitian menyebutkan bahwa hampir semua anggota kelompok LGBT di di Indonesia mengalami diskriminasi dan kekerasan. Kasus-kasus yang terjadi di delapan daerah tersebut beragam mulai dari pengusiran, cemoohan, pengucilan, pelecehan seksual, pemukulan, penganiayan, hingga pembunuhan. Namun, sayangnya, perhatian pdan respon pemerintah dan aparat terkait pada kekerasan yang menimpa LGBT sangat minim.

\section{Tindakan sosial}

Konsep tindakan sosial telah banyak diungkapkan oleh tokoh-tokoh sosiologi. Karl Marx yang menyebutkan bahwa tindakan sosial adalah tindakan-tindakan produktif (kerja) yang bertujuan mengolah alam dan material demi mencapai tujuan tertentu. Emile Durkheim juga mengungkapkan bahwa tindakan sosial merupakan reaksi dari sebuah fakta sosial yang mengikat dan memaksa individu (Ritzer \& Goodman, 2010 : 53 \& 81). Menurut Max Weber, tindakan sosial adalah tindakan individu yang mempunyai makna dan arti subjektif bagi dirinya sendiri dan diarahkan kepada tindakan orang lain. Weber menyebutkan bahwa dari segi sasarannya, tindakan sosial dapat diarahkan kepada seorang individu atau sekumpulan orang. Sebuah tindakan yang diarahkan kepada benda mati bukanlah merupakan tindakan sosial. Tindakan sosial adalah tindakan yang dilakukan oleh individu pada individu atau pada kelompok yang menimbulkan reaksi penuh arti. Weber mengkategorikan tindakan sosial menjadi empat tipe yaitu: rasionalitas instrumental, rasionalitas tujuan, tindakan afektif, dan tindakan tradisional (Ritzer, 2010 : 38-40).

\section{Interaksionisme simbolik}

George Herbert Mead merumuskan beberapa prinsip dasar dari interaksionisme simbolik, yaitu:

1. Kemampuan berpikir.

Kemampuan berpikir memungkinkan individu bertindak secara reflektif dan bukan sekedar bertindak. Individu memiliki otak untuk mengembangkan pikiran, tetapi otak tidak serta-merta menghasilkan pikiran. Pikiran adalah bagian dari proses stimulus dan respon yang berhubungan dengan sosialisasi, makna, simbol, diri, interaksi, bahkan masyarakat.

2. Berpikir dan interaksi.

Interaksionisme simbolis menekankan pada bentuk interaksi yang lebih spesifik yaitu sosialisasi. Sosialisasi adalah proses dinamis yang memungkinkan individu mengembangkan kemampuan berpikir, dan tumbuh secara manusiawi. Sosialisasi merupakan bagian dari interaksi secara umum, interaksi itu sendiri adalah proses kemampuan berpikir yang dikembangkan dan diapresiasikan. Sebagian besar interaksi perlu pertimbangan untuk bertindak.

3. Mempelajari makna dan simbol.

Simbol merupakan objek sosial yang digunakan untuk merepresentasikan sesuatu yang telah disepakati bersama. Interaksionisme simbolik memahami bahwa dalam sebuah interaksi sosial individu mempelajari simbol sekaligus maknanya. Mempelajari simbol dan makna memungkinkan individu untuk berhubungan dengan dunia materi dan dunia sosial, karena dengan simbol ia dapat memberi nama, membuat kategori, dan mengingat objek yang ditemui. Simbol juga meningkatkan kemampuan individu mempersepsikan lingkungannya. Selain itu, simbol juga meningkatkan kemampuan berpikir dan meningkatkan kemampuan individu untuk memecahkan masalah. Peran simbol lainnya adalah memungkinkan aktor melampaui ruang, waktu, dan bahkan pribadi mereka sendiri. Simbol juga memungkinkan individu untuk membayangkan realitas metafisis, seperti surga dan neraka.

4. Tindakan dan interaksi.

Pokok perhatian interaksionisme 
simbolik adalah pada dampak makna dan simbol pada tindakan dan interaksi manusia. Tindakan sosial pada umumnya melibatkan aktor tunggal, sedangkan interaksi sosial melibatkan dua aktor atau lebih. Dalam tindakan sosial, individu mencoba untuk memperkirakan dampaknya pada individu lain yang terlibat. Di dalam interaksi sosial, individu terlibat dalam proses saling mempengaruhi.

5. Menetapkan pilihan.

Di dalam interaksionisme simbolik, aktor memiliki otonomi, dan tidak hanya sekedar dan diarahkan. Para individu mampu menetapkan pilihan yang bebas. Individu tidak perlu menerima makna dan simbol yang berasal dari luar, ia bebas untuk menentukan simbol dan makan ber-dasarkan tafsir pribadi (Ritzer \& Goodman, 2010: 393-396).

\section{Metode Penelitian}

Penelitian ini bertujuan menggali langkahlangkah konkrit yang dilakukan oleh Yayasan Gaya Dewata dalam mengurangi penyebaran HIV-AIDS di Bali dan mengetahui upaya yayasan dalam mengatasi hambatan dan tantangan dalam aktivitasnya tersebut. Teknik pengumpulan data pada penelitian ini dilakukan dengan melakukan wawancara mendalam dan studi literatur. Wawancara mendalam dilakukan terhadap informan untuk mengetahui dengan detil bentuk dan jenis kegiatan yang dilakukan YGD. Studi dokumen juga dilakukan untuk mem-peroleh data pendukung, seperti data hasil yang dilakukan oleh yayasan. Hasil penelitian ini disajikan dalam teks deskriptif.

\section{Hasil dan Pembahasan}

\section{Profil Yayasan Gaya Dewata}

Yayasan Gaya Dewata adalah LSM yang didirikan oleh para gay. Tujuan pendirian yayasan adalah untuk menaungi para gay dalam berbagai kegiatan kemasyarakatan, termasuk dalam kegiatan pencegahan dan penanggulangan HIV dan AIDS. Yayasan ini berdiri secara informal pada tanggal 14 Februari 1992, diprakarsai oleh beberapa orang dari komunitas gay di Bali. Pada mulanya, yayasan ini bernaung dibawah Yayasan Citra Usadha (YCU). Namun, pada 1999 Yayasan Gaya Dewata memisahkan diri dan resmi menjadi organisasi formal tersendiri. Yayasan Gaya Dewata kemudian dikukuhkan dengan akta notaris dan terdaftar secara sah di Departemen Hukum dan HAM RI pada tanggal 21 Agustus 2009 (Yayasan Gaya Dewata, 2014).

Yayasan Gaya Dewata berafiliasi dengan Yayasan Gaya Nusantara, yaitu lembaga swadaya masyarakat yang diprakarsai dan diperuntukkan bagi kelompok LGBT di Indonesia. Jika Yayasan Gaya Dewata berada di tingkat daerah, maka Yayasan Gaya Nusantara berada di tingkat nasional. Yayasan Gaya Dewata juga berpartisipasi dalam kegiatan-kegiatan di tingkat nasional bagi kaum LGBT. Salah satu agenda kegiatan seluruh yayasan gay di Indonesia adalah menegakkan hak-hak kaum LGBTI hingga saat ini belum terpenuhi (Oetomo, 2006: 6).

Pada awalnya, Yayasan Gaya Dewata mengalami kesulitan-kesulitan dalam menjalankan program-program pencegahan dan penanggulangan HIV-AIDS. Hal itu terjadi karena pemerintah memarginalkan Yayasan Gaya Dewata. Hal ini berkaitan dengan kuatnya heteroseksisme dan homofobia di kalangan pemerintah (Oetomo, 2006 : 8). Namun, keadaan perlahan-lahan membaik setelah Yayasan Gaya Dewata terpilih sebagai salah satu organisasi yang memperoleh bantuan dari lembaga donor yaitu HIV Cooperation Program for Indonesia (HCPI) dari Australia dan New Funding Model Global Fund, sebuah lembaga donor multinasional.

Setelah mendapatkan dana dari lembaga donor, pada 7 Agustus 2012, Yayasan Gaya Dewata membentuk divisi Pelangi Muda Dewata sebagai wadah untuk gay, waria, lesbian, biseksual, dan transgender muda di Bali. Selain itu, tujuan pembentukan divisi 
ini adalah untuk melaksanakan kegiatan menekankan pada upaya pencegahan dan penanggulangan HIV dan AIDS.

\section{Kegiatan Yayasan Gaya Dewata}

Aktivitas Yayasan Gaya Dewata (YGD) pada awalnya dilakukan oleh aktivis secara sukarela dan secara tidak teratur. Namun, saat ini kegiatan lebih terarah dan terstruktur dengan adanya program-program yang telah disepakati oleh YGD dengan lembaga donor. Meski kegiatan yayasan sebagian besar didukung secara finansial oleh donor multinasional, berhentinya dana dari donor tidak menjadikan kemandirian YGD dalam melakukan kegiatan berkurang atau bahkan hilang.

YGD adalah organisasi yang benar-benar mengakar rumput, dimana terkadang tampak lebih seperti kelompok sosial organik dari pada sekedar Lembaga Swadaya Masyarakat yang terdaftar secara formal (Ramonès, 2015). Pendapat Ramonès (2015) tersebut diperkuat oleh pernyataan Krisna, salah satu pendiri YGD; "YGD adalah dari komunitas, untuk komunitas. YGD ada dari komunitas”.

Saat ini YGD memiliki kegiatan berupa 1) intervensi individu oleh Petugas penjangkau atau petugas outreach (PO), 2) cyber outreach, 3) Diskusi Interaktif Kelompok (DIK) dengan anggota komunitas populasi kunci HIV, 4) distribusi kondom dan pelicin, 5) konseling dan tes HIV, dan 6) dukungan pada orang dengan HIV AIDS (ODHA).

1) Intervensi individu

Kegiatan ini dilakukan oleh Petugas Penjangkau (atau dikenal dengan istilah Petugas Outreach/PO). Kegiatan ini dilakukan untuk menjangkau kelompok LGBT di Bali. Anggota kelompok LGBT yang belum bergabung di YGD didekati oleh PO dan diajak untuk bergabung di yayasan. Selain menjangkau calon anggota baru, kegiatan intervensi juga meliputi kegiatan mendampingi para LGBT yang telah menjadi anggota YGD oleh para PO. Kegiatan pendampingan berisi pemberian informasi oleh para PO pada anggota. Informasi yang diberikan meliputi kesehatan seksual, penyakit infeksi menular seksual (IMS) dan HIV serta dan pencegahan, serta informasi tempat layanan IMS dan VCT (Voluntary Counselling and testing/ konseling dan tes sukarela) dan prosedurnya. Saat ini Petugas penjangkau dari Yayasan Gaya Dewata telah melakukan kegiatan intervensi di tiga kabupaten/kota di Provinsi Bali yakni Kota Denpasar, Kabupaten Badung, dan Kabupaten Gianyar. Hingga 2015 pata aktivis di yayasan telah berhasil menjangkau 260 anggota baru dan mendampingi 594 orang anggota (Yayasan Gaya Dewata, 2015).

2) Cyber Outreach.

Selain kegiatan penjangkauan lapangan, YGD juga melakukan kegiatan penjangkauan melalui jejaring sosial di dunia maya. Website yang sering digunakan oleh komunitas LGBT di Indonesia saat ini antara lain:

www.gayromeo.com, wWw.manjam.com, www.gaydar.com, www.gay.com, facebook, tweeter, GRINDR, satu room GIM di MIRC-DALnet).

Berbeda dengan bentuk penjangkauan oleh PO di lapangan, bentuk penjangkauan cyber outreach dilakukan melalui update status, penyampaian pesan dan bisa langsung chatting dengan para gay, para lelaki yang tidak menyebut diri gay tetapi juga melakukan hubungan seks dengan lelaki (dikenal dengan sebutan lelaki seks dengan lelakidisingkat LSL) dan remaja. Hingga September 2014, kegiatan cyber outreach telah berhasil menjangkau 505 orang.

3) Kegiatan Diskusi Interaktif Kelompok.

Kegiatan ini bertujuan untuk mengubah pengetahuan dan perilaku anggota terutama perilaku penggunaan kondom pada saat 
aktivitas seksual. Kegiatan ini dilakukan dua kali setiap bulan oleh Petugas penjangkau. Satu kelompok diskusi diikuti rata-rata oleh 10 orang terdiri atas anggota anggota yang sudah maupun belum positif HIV atau AIDS. Petugas penjangkau bertindak sebagai fasilitator. Pada 10 bulan kegiatan ini berjalan, sebanyak 1.300 orang telah mengikuti kegiatan ini.

4) Distribusi Kondom

Para aktivis membagikan kondom dan pelicin secara gratis kepada para jangkauan mereka. Kondom dan pelicin disediakan oleh Komisi Penanggulangan AIDS Nasional. Setiap bulan waria yang dijangkau menerima 15 buah kondom dan 8 sachet pelicin, sementara non waria menerima 10 buah kondom dan 5 sachet pelicin.

5) Konseling dan tes HIV.

Kegiatan ini dilakukan setiap hari oleh para PO dan dilakukan baik di luar atau di kantor YGD sesuai kebutuhan dan kenyamanan orang yang ingin menjalani konseling dan tes. Konseling diberikan oleh para konselor HIV di klinik yang bekerjasama dengan YGD. Tes pun dilakukan oleh petugas kesehatan di tempat yang sama. Hingga 2014. YGD telah merekrut 40 orang jangkauan untuk mengikuti VCT.

6) Dukungan pada ODHA

YGD juga memiliki kegiatan yang bertujuan memberikan dukungan pada Orang dengan HIV dan AIDS (ODHA). Semua aktivis yang bertugas sebagai penjangkau lapangan diwajibkan oleh yayasan untuk mendampingi ODHA. Tujuan kegiatan tersebut untuk mengetahui lokasi ODHA dan memastikan mereka menerima layanan yang dibutuhkan, mematuhi jadwal minum obat bagi yang sudah mengikuti terapi pengobatan HIV, serta memastikan perilaku konsistensi mereka dalam penggunaan kondom.

Di dalam melaksanakan kegiatannya, YGD seringkali menghadapi berbagai hambatan. Beberapa hambatan yang dihadapi antara lain: masih adanya stigma pada LGBT di masyarakat sehingga mereka cenderung menyembunyikan diri dan sulit dijangkau; masih banyak waria di Bali yang masih sering melakukan perbuatan yang melanggar aturan dan berbuat kriminal sehingga memperkuat stigma dari masyarakat dan aparat terhadap mereka; adanya preman dan orang yang tidak toleran dengan kelompok LGBT yang menghambat kerja petugas penjangkau.

Langkah yang dilakukan YGD untuk mengatasi dan mengantisipasi berbagai hambatan tersebut adalah dengan memberikan pemahaman kepada komunitas LGBT di Bali terkait permasalahan HIVAIDS. Yayasan juga sering mengundang orang-orang LGBT yang dianggap sebagai role model bagi rekan-rekan sesamanya.

Para petugas penjangkau YGD juga berupaya meningkatkan kewaspadaan dalam melaksanakan tugasnya dengan baik dan menghindari permasalahan dengan para preman. Saat ini, kegiatan cyber outreach cukup efektif untuk menekan permasalahan yang sering muncul dalam kegiatan penjangkauan lapangan; dan mampu menjangkau para anggota LGBT yang masih menyembunyikan dirinya di masyarakat.

YGD juga bekerjasama dengan organisasi lain yang bergerak dalam kegiatan serupa; menjalin kerjasama dan koordinasi dengan berbagai pihak baik instansi pemerintah, organisasi non pemerintah, LSM, berbagai jenis usaha, hingga pihak media. Yayasan Gaya Dewata saat ini bekerjasama dengan Dinas Kesehatan dan Dinas Sosial (Dinkes dan Dinsos) Provinsi Bali, dalam melakukan pelatihan skill building bagi kelompok gay, waria, lelaki seks dengan lelaki (LSL), dan OdHA. YGD juga bekerjasama dengan Dinas Pariwisata Provinsi Bali/ kabupaten/ kota. Dinas Pariwisata membantu YGD dalam memfasilitasi dialog antara YGD dengan pemilik tempat hiburan (cafe, bar, dan restaurant) di daerah jangkauan yayasan. Yayasan juga ber-koordinasi dengan Komisi Penanggulangan AIDS (KPA) Provinsi Bali maupun KPA kabupaten/ kota, dalam 
melakukan advokasi untuk keberadaan kelompok dampingan gay, waria, dan LSL.

Selain menjalin koordinasi dan kerjasama dengan berbagai dinas dan KPA, YGD juga berkoordinasi dengan berbagai tempat hiburan, salon, dan panti pijat. Cafe dan Bar (Bali Beach Shark, Mixwell Bar, Bali Joe Bar \& Lounge) menjadi lokasi penjangkauan oleh para aktivis YGD. Di lokasi-lokasi tersebut banyak para gay yang sering berkumpul dan ada beberapa dari mereka yang menjadi pekerja seks. Kerjasama yang terjalin antara YGD dan pemilik usaha diwujudkan dalam bentuk penyediaan fasilitas tempat untuk pelak-sanaan outreach dan penyuluhan yang diadakan YGD di café tersebut. Selain kafe, berbagai salon dan panti pijat tempat KD bekerja menjadi lokasi untuk mendis-tribusikan media Komunikasi, Informasi, dan Edukasi (KIE), menjadi tempat untuk diskusi lapangan dan outlet penjualan kondom.

YGD juga menjalin kerjasama dengan berbagai lokasi rujukan layanan kesehatan untuk mendukung kegiatan konseling dan tes HIV. Beberapa lokasi rujukan layanan kesehatan dan pengobatan yakni Rumah Sakit Umum Sanglah, layanan di bawah pengawasan Dinas Kesehatan provinsi/ kabupaten/ kota. Kerjasama juga dilakukan dengan beberapa media cetak dan elektronik, untuk memberitakan seputar kegiatan yang dilakukan oleh YGD. Selain itu YGD juga berkerjasama dengan lembaga swadaya masyarakat lainnya dalam layanan pemeriksaan dan pengobatan IMS dan HIV-AIDS, maupun untuk dukungan terhadap OdHA.

\section{Pembahasan}

Berbagai kegiatan yang dilakukan oleh Yayasan Gaya Dewata merupakan wujud tindakan sosial. Merujuk pada definisi yang dikemukakan Weber, kaum gay dan waria yang menjadi aktivis di Yayasan Gaya Dewata, melakukan tindakan sosial yang diwujudkan melalui berbagai kegiatan penanggulangan HIV dan AIDS.Kegiatankegiatan tersebut diarahkan kepada kelompok LBGT dengan harapan dapat mewujudkan perubahan perilaku anggota kelompok tersebut agar lebih sehat dan terhindar dari HIV-AIDS.

Weber (dikutip dalam Wirawan, 2012: 101) membagi konsep tindakan rasional menjadi empat tipe yakni :

1. Rasionalitas instrumental; yaitu tindakan yang dilakukan dengan mempertimbangkan tujuan dan alat yang digunakan untuk mencapai tujuan.

2. Rasionalitas tujuan, yaitu tindakan tujuannya telah ditentukan; alat-alat dan perhitungan hanya sekedar sebagai pelengkap mencapai tujuan

3. Tindakan afektif yaitu tindakan yang dilakukan dengan didasari oleh perasaan atau emosi aktor, tanpa adanya refleksi intelektual.

4. Tindakan tradisional yaitu, tindakan yang dilakukan berdasarkan kebiasaan tanpa adanya perencanaan

Kegiatan yang dilakukan oleh para gay dan waria yang menjadi aktivis di Yayasan Gaya Dewata termasuk tipe tindakan rasionalitas instrumental dan tindakan afektif. Kegiatan tersebut dikategorikan sebagai tindakan rasionalitas instrumental karena tujuan dari tindakan tersebut bersifat instrumental yaitu bertujuan mengurangi penyebaran HIV-AIDS di Bali. Upaya mencapai tujuan dilakukan dengan menggunakan berbagai alat yakni berbagai bentuk kegiatan; yang meliputi intervensi individu oleh Petugas Outreach (PO), cyber outreach, Diskusi Interaktif Kelompok (DIK), distribusi kondom dan pelicin, konseling dan tes HIV, dan dukungan pada ODHA. Selain itu, mereka juga melakukan kegiatan lokakarya, seminar pendekatan, hingga menjalin kerjasama dengan berbagai pihak. Berbagai alat dan cara tersebut digunakan untuk mencapai tujuan.

Selain dikategorikan sebagai tindakan rasional instrumental, kegiatan para aktivis di Yayasan Gaya Dewata dapat dikategorikan sebagai tindakan afektif. Kaum 
gay dan waria yang menjadi aktivis di Yayasan Gaya Dewata melakukan berbagai kegiatan tersebut dengan didorong oleh emosi mereka pada orang yang dijangkau. Emosi tersebut muncul karena para aktivis memiliki kesamaan pengalaman, latar belakang kehidupan, dan juga perasaan prihatin kepada sesama LGBT. Namun, berbeda dengan kategori tindakan afektif pada umumnya, para aktivis di Yayasan Gaya Dewata, selain menggunakan perasaan dan emosi dalam berkegiatan mereka juga menggunakan kemampuan intelektualnya. Mereka mengembangkan kemampuan intelektual untuk dapat menyebarkan informasi, membantu memecahkan persoalan yang dihadapi, serta mengarahkan jangkauan mereka untuk memperoleh layanan kesehatan. Tanpa mengerahkan kemampuan intelektual, berbagai kegiatan yang dilakukan para aktivis tidak dapat berjalan maksimal dan berkesinambungan.

Kegiatan para aktivis di Yayasan Gaya Dewata tak hanya dapat dianalisis melalui konsep tindakan sosial Weber, tetapi juga dapat dianalisis dengan menggunakan perspektif teori interaksionisme simbolik. Gay \& waria sebagai seorang individu tentunya memiliki latar belakang kehidupan yang berbeda, begitu pun pendidikan, dan budaya keluarga mereka. Yayasan Gaya Dewata memiliki visi dan misi untuk menyatukan seluruh perbedaan tersebut dengan tujuan mengurangi penyebaran HIVAIDS di Bali.

Secara garis besar, tindakan para aktivis dapat dilihat dari lima prinsip dasar interaksionisme simbolik: 1) kemampuan berpikir; 2) kemampuan berpikir dan berinteraksi, 3) memepelajari makna dan symbol, 4) tindakan dan interaksi, 5) penetapan pilihan.

Sejalan dengan prinsip pertama, berbagai tindakan sosial yang dilakukan oleh para aktivis diawali oleh proses berpikir yang selanjutnya berkembang menjadi tindakan. Pola pikir para aktivis semakin berkembang seiring dengan stimulus dan respon yang mereka peroleh dari lingkungan sekitar; yaitu situasi dan kondisi yayasan yang berkegiatan dengan tujuan mengurangi penyebaran HIV-AIDS. Kemampuan berpikir merupakan dasar bagi para aktivis untuk melakukan aksi sosialnya untuk menemukan jalan keluar dari permasalahan yang dihadapi, walaupun kebanyakan masih sebatas rencana pemecahan masalah.

Sesuai dengan prinsip yang kedua yakni berpikir dan berinteraksi, para aktivis yayasan melakukan interaksi yang diimplementasikan dalam bentuk kegiatan sosialisasi pada para jangkauan. Pada proses ini para aktivis membuat aneka pertimbangan dan apresiasi dalam bertindak. Yayasan telah melakukan penelitian dan selalu melakukan pemantauan terhadap penyebaran virus HIV, sehingga mereka selalu mempertimbangan dengan matang kegiatan yang sesuai untuk mendorong pencegahan dan penyembuhan bagi para jangkauan. Mereka juga memperkuat prinsip ini melalui aksi-aksi lokakarya dan diskusi dengan berbagai pihak untuk mewujudkan tujuan kegiatan mereka.

Prinsip ketiga yakni mempelajari makna dan simbol. Di dalam dunia LGBT terdapat banyak simbol. Salah satunya adalah kegiatan yang dinamai "Condom Man". Kegiatan ini adalah sebuah aksi membagikan kondom secara gratis kepada masyarakat di beberapa tempat di kota-kota besar di Bali. Sesuai dengan nama kegiatannya yakni "Condom Man", aktivis yang bertugas adalah laki-laki. Di Bali, kegiatan ini memicu berbagai reaksi dari masyarakat. Pesan yang ingin disampaikan dan ditekankan oleh yayasan dan aktivis pada masyarakat adalah untuk melakukan seks yang tidak beresiko. Namun, para aktivis berpendapat bahwa setiap individu bebas untuk memaknai simbol dari kegiatan tersebut dan mereka tetap menjalankan kegiatannya; terlepas dari aneka reaksi yang muncul dari masyarakat.

Prinsip keempat adalah tindakan dan interaksi. Prinsip ini membedakan antara tindakan sosial dan interaksi sosial. Yayasan selalu mempertimbangkan 
dampak dari tindakan sosial yang mereka lakukan; apakah akan menimbulkan konflik baru atau akan diterima oleh masyarakat. Saat ini kegiatan-kegiatan yang dilaksanakan yayasan telah diterima dengan baik oleh masyarakat dan pihak terkait. Proses yang terjadi setelahnya adalah proses saling mempengaruhi yaitu dalam hal mempengaruhi pola hidup seseorang untuk terhindar dari HIV-AIDS.

Prinsip kelima yakni menetapkan pilihan. Penetapan pilihan merujuk pada tahap ketika seorang individu berhak untuk menentukan pilihannya untuk mengikuti atau tidak mengikuti kegiatan yayasan. Tahap ini merupakan lanjutan dari tahap sebelumnya yaitu tahap saling mempengaruhi. Simbol dan makna dibentuk oleh yayasan dan diwujudkan melalui kegiatan-kegiatan. Namun, kegiatan tidak dengan mudah diterima oleh masyarakat tergantung dari pemaknaan dan penerimaan simbol tersebut oleh masyarakat.

Merujuk pada lima prinsip dasar interaksionisme simbolis, kegiatan yang dilakukan oleh Yayasan Gaya Dewata adalah serangkaian simbol yang dimaknai secara beragam oleh masyarakat. Oleh karena itu, aksi-aksi sosial yang dilakukan oleh yayasan, menimbulkan reaksi yang beragam di masyarakat. Pada setiap kegiatan, tujuan utama yayasan bukan sekedar pada penerimaan kegiatan oleh masyarakat, melainkan pada kemauan masyarakat bekerja sama dengan yayasan dalam kegiatan mengurangi penyebaran HIV dan AIDS.

Pemikiran Mead mengenai interaksionisme simbolis tertuang dalam beberapa konsep seperti pikiran, diri, dan masyarakat. Mead mendefinisikan pikiran sebagai proses percakapan batin individu dengan dirinya. Hal ini tidak ditemukan di dalam diri orang lain. Pikiran muncul dan berkembang di dalam proses sosial. Proses sosial seringkali disertai dengan aneka permasalahan sehingga proses berpikir merupakan ruang bagi individu untuk mencari jalan keluar dari permasalahan-permasalahannya. Para gay dan waria, sebagai kelompok minoritas, tentu saja sering melakukan percakapan batinmengenai seluruh pengalaman dalam hidupnya. Percakapan batin mereka diwadahi dengan baik oleh Yayasan Gaya Dewata; yaitu dengan cara mengarahkan para anggota untuk tidak hanya memikirkan masalah pribadi sebagai gay dan waria, tetapi juga memikirkan isu kesehatan, terutama HIV dan AIDS di masyarakat luas.

Mead juga mendefinisikan konsep diri dideskripsikan sebagai kemampuan individu menjadikan dirinya sendiri sebagai objek maupun subjek. Konsep diri bukan merujuk pada tubuh secara fisik melainkan tapi pada tubuh yang memiliki pikiran. Individu dapat dikatakan memiliki jati diri dan kepribadian apabila ia telah melalui proses berpikir yang berkembang.

Mead juga menjelaskan konsep masyarakat. Baginya masyarakat merepresentasikan serangkaian respon terorganisasi yang diambilalih oleh individu. Masyarakat terdiri dari individu-individu yang memberikan kemampuan melalui kritik-kritik, untuk mengontrol diri mereka sendiri (Ritzer dan Goodman, 2010: 385-391). Para gay dan waria di Bali berupaya untuk merespon kritik dan stigma yang ditujukan pada mereak oleh warga masyarakat umum dan berupaya mengontrol diri mereka sendiri dalam menghadapi kritik-kritik tersebut serta tetap berkonsentrasi pada kegiatan mereka serta manfaatnya bagi amsyarakat luas.

\section{Simpulan}

Peran Yayasan Gaya Dewata untuk dalam menanggulangi HIV-AIDS di Provinsi Bali khusunya di Kota Denpasar, Kabupaten Badung, dan Kabupaten Gianyar diwujudkan melalui berbagai kegiatan yakni, intervensi individu oleh Petugas Outreach (PO), cyber outreach, Diskusi Interaktif Kelompok (DIK), distribusi kondom dan pelicin, konseling dan tes HIV, dan dukungan pada ODHA. Para aktivis di yaysan tersebut adalah para gay dan waria. Di dalam melaksanakan kegaitan, mereka menemui beberapa hambatan; yaitu stigma dari 
masyarakat terkait orientasi seksual mereka dan juga terkait banyaknya waria yang masih melakukan perbuatan yang melanggar aturan sosial dan berbuat kriminal; adanya preman atau orang yang tidak toleran pada para gay dan waria; masih banyaknya para gay dan waria di masyarakat yang menyembunyikan diri dan masih enggan bergabung dengan yayasan. Para aktivis di Yayasan mengatasi hambatan tersebut dengan cara memberikan pemahaman mengenai pentingnya pencegahan dan penanggulangan HIV dan AISD kepada para gay dan waria yang belum bergabung di yayasan; bekerjasama dengan organisasi yang bergerak di bidang pencegahan dan penanggulangan HIV untuk bersama-sama memberikan informasi pada masyarakat luas; meningkatkan kewaspadaan dalam melaksanakan tugasnya serta sebisa mungkin menghindari permasalahan dengan para preman, dan terakhir meningkatkan intensitas pendekatan dengan metode cyber outreach untuk menjangkau KD yang terselubung.

Kegiatan yang dilakukan oleh para aktivis di Yayasan Gaya Dewata serta upaya mereka mengatasi berbagai hambatan yang ditemui merupakan wujud dari tindakan sosial. Tindakan sosial yang mereka lakukan masuk dalam kategori tindakan rasionalitas instrumental dan tindakan sosial afektif. Para aktivis menjadikan kegiatan mereka sebagai mencapai tujuan lembaga yakni mengurangi penyebaran HIV dan AIDS pada kelompokkelomook di masyarakat yang rawan terinfeksi HIV. Tidak hanya berorientasi pada pencapaian tujuan, para aktivis melakukan berbagai kegiatan dengan didasari oleh perasaan dan emosi serta kepedulian mereka pada para gay dan waria yang belum bergabung di yayasan dan belum memiliki ketrampilan serta kemampuan untuk mencegah diri dari infeksi HIV.

Tindakan para aktivis didasari oleh kemampuan mereka dalam berpikir. Hasil dari proses berpikir tersebut, mereka terapkan dalam berbagai kegiatan yang diselenggarakan oleh yayasan. Pada akhirnya kegiatan yang dilakukan oleh para aktivis dalam upaya mencegah dan menanggulangi penyebaran HIV dan AIDS di Bali, merupakan hasil dari proses berpikir; dan yang pada saat bersamaan menunjukkan jati diri baik mereka sebagai gay dan waria yang pada dasarnya merupakan bagian dari masyarakat dan memiliki tanggungajwab yang sama dengan warga lainnya dalam hal mencegah dan menanggulangi penyakit.

\section{Daftar Pustaka}

Arianto; Triawan; R. 2008. Jadi, Kau Tak Merasa Bersalah!?: Studi Kasus Diskriminasi dan Kekerasan Terhadap LGBTI. Jakarta: Citra Grafika.

Goodman, Douglas J; Ritzer, G. 2010. Teori Sosiologi: Dari Teori Sosiologi Klasik Sampai Perkembangan Mutakhir Teori Sosial Postmodern. Bantul: Kreasi Wacana

Kartono, Kartini. 2007. Patologi Sosial. Jakarta: PT RajaGrafindo Persada.

Kirven, S.; Louis, E.E; Marie, C. 2010. New Protection Manual for Human Rights Defender. (Tedja Bayu Trans). Belgia: Protectional Internasional \& Arus Pelangi

Oetomo, Dédé. (2006). Memperjuangkan Hak Asasi Manusia Berdasarkan Identitas Gender dan Seksualitas di Indonesia. Diakses pada 18 Juni 2017. http://s3.amazonaws.com/academia.edu .documents/34834860/Memperjuangka n_HAM_Berdasarkan_Gender_Seks ualitas_di_Indonesia_Komnas_HAM 2006.pdf?AWSAccessKeyId=AKIAI

WOWYYGZ2Y53UL3A\&Expires $=14$ 97793033\&Signature $=$ B89B\%2BqExB MqL14bLOU7ODZYTg80\%3D\&resp onse-content-

disposition=inline $\% 3 \mathrm{~B} \% 20$ filename $\% 3$ DMemperjuangkan_Hak_Asasi_Manus ia Berdasa.pdf

PT GRM International (PT GRM) dan Yayasan Gaya Dewata Bali (2015). Partner Grant (A) Contract for HIV Cooperation Program for Indonesia: HIV Prevention, Sexsual Reproductive for MSM in Kota Denpasar, Kab. Badung and Kab. Buleleng. Jakarta dan Denpasar: PT GRM dan YGD

Ramonès, Ikaika. (2015). Cus M! Let's Go!: The Flourishing of Bali's Komunitas Gay in the HIV/AIDS Crisis. Diakses 18 Juni 2017. http://digitalcollections. 
sit.edu/cgi/viewcontent.cgi?article=325 4\&context=isp_collection

Ratu, Titian. (Juni 2012). Universitas Indonesia. Analisis Wacana Homoseksualitas Di Dalam Film All You Need Is Love - Maine Schwiegretochter ist Eein Mann. Diakses pada 15 November 2014. lib.ui.ac.id/file?file=digital/20297065S1926.pdf

Ritzer, George. (2011). Sosiologi Ilmu Pengetahuan Berparadigma Ganda. Jakarta, RajaGrafindo Persada

Wirawan, I.B. (2012). Teori-Teori Sosial Dalam Tiga Paradigma: Fakta Sosial, Definisi Sosial, \& Perilaku Sosial. Jakarta, Kencana

Website resmi Kementerian Kesehatan RI. Diakses pada 1 Agustus 2015. www.depkes.go.id

Website resmi Yayasan Gaya Dewata. Diakses pada 5 Juni 2014. http://gaya dewata.com. 